\title{
Preface
}

The $16^{\text {th }}$ volume of Cracow Indological Studies, which we would like to dedicate to the memory of Mr. Józef Lączak, concentrates on Tantric traditions of South Asia, just as the $8^{\text {th }}$ volume, published in 2006. The contributions to the present volume refer both to the topic of the theoretical side of these traditions and to practical issues; some of them pertain also to the mutual relations between theory and practice.

The research on Tantric traditions of India, although based mostly on textual sources, deals also with the practical application of the textual prescripts into the daily practice of the followers and into the temple rituals. Therefore, besides inquiring into the theological and philosophical issues within the vast body of canonical scriptures and exegetical texts, scholars search for traces of actual practice. The mutual relation of the prescriptive or normative literature and the actual shape of the tradition is similarly interesting with regard to the past as well as to present-day India.

Since our knowledge about the textual sources is growing, also due to several research projects dedicated to collecting new, hitherto unknown texts, scholars gain access to more source materials and are able to deepen or re-consider their views conceming the traditions under research. New data is provided by archaeology and history research; anthropological and ethnological inquiry into the stillliving traditions has also become one of the important components of Indological research. Thus better knowledge and understanding of Tantric traditions is made possible duc to the involvement and cooperation of different disciplines: history of the region, ethnography, epigraphy, archeology, art history and obviously philology. 
The present $16^{\text {th }}$ volume of Cracow Indological Studies is therefore meant for contributions concerning several issues connected with the new developments in the study on the textual sources as well as the more practical dimensions of Tantric traditions.

Tantric traditions of South Asia created rich literature, an extensive part of which was viewed as canonical and revealed by the highest god himself, though collected and systematized by men. The theoretical needs imposed by the canonical scriptures, claiming also to belong to Brahmins (which very often was the case because it was mostly Brahmins who created them), were meeting the practical needs of the actual situation. Traditions, existing in the particular space and time, in their daily practice had to acknowledge and react to those needs. Some of these traditions were heterodox, unconventional and they openly presented their sometimes controversial views despite the critical opinions of the Brahmanical and orthodox milieu. Other ones tried as much as possible to adapt their ideas to the mainstream of the surrounding traditions. Thus, being subject to internal and external influences, they included elements rooted in the orthodox cults, but also those coming from the local and heterodox cults; some of them contain also elements which transgress orthodox norms. The process of combining strands of different traditions can be observed for example in the South of India, where the Brahmanical culture was interacting with the local, social specificity and local religious traditions of Dravidian origin.

Additionally, the theoretical canon has to interact with the ritualistic and technical needs of religious practice arising from the necessity of ensuring the proper place of worship, adequate representation of the god and efficient procedure of worshipping him.

The relation of the theory and practice draws attention of several scholars, therefore the present volume inscribes also in these streams of Indological research.' Axel Michaels, in his General Preface

1 One can refer here for example to the volumes resulting from the research of the group of scholars working in Heidelberg in the frame of the Collaborative Research Center Dynamics of Rituals. 
to the "Heidelberg Studies in South Asian Rituals", points out that the study of rituals in South Asia for a long time existed in between philology and anthropology, but nowadays more often field-work and the study of texts are combined. ${ }^{2}$ It makes Indological research more interdisciplinary. Nevertheless, the research on textual sources still becomes indispensable to the acquisition of knowledge about theoretical doctrines as well as practical aspects of the traditions under research. However, not having enough sources about the history of reception of the theoretical texts (see for example Rastelli, in the present volume), we have to be cautious about referring scriptures to present-day ritualistic practice directly. The authors of the Words and Deeds volume even warn us about such danger. ${ }^{3}$ Similarly, some of the authors of the present volume draw our attention to the fact that the texts are usually normative and that it would be difficult to answer the question to what extent they were put into practice. Nevertheless, theoretical rules were probably quite often influenced by actual contemporary practice and also by contemporary context. ${ }^{4}$ Thus in the texts one

\section{Michaels 2005.}

3 Gengnagel, Hüsken and Raman (Gengnagel et al. 2005: 18) write: "However, a reliance on field observations should not induce one to read ancient texts in the light of present day practice, for this would be tantamount to assuming that such texts corroborate actual practice despite obvious discrepancies between the two. Those who are philologists, though, should be clear about the distinction between theological literature and ritual texts. The latter are often meant to be read and understood in close connection with particular ritual actions, their prescriptions being permanently connected to interpretive performances. A philological approach which narrowly and exclusively focuses on linguistic criteria is not appropriate for the study of texts composed in order to communicate a subjectmatter which should be comprehensible within a milieu of ritual practitioners. Hence, Colas makes a strong plea for situating ritual texts within their historical context. The challenge his article poses is addressed in one way or the other by all the papers in these two volumes."

About the role of the texts in contexts and the role of exegesis in constituting this context see for example Timm 1992. 
can find traces of insertions which document the particular stage in the history of the development of a tradition. Sometimes the texts included and described some notions which cannot be observed later. Even if we admit that the appearance of some notions and, for example, some specific classifications could have been slightly artificial and secondary attempts to fill some postulated gaps within a doctrine, they nevertheless could really document a historical reality of a particular epoch. Such could be the case of different categories of devotecs listed and described in some Tantric texts (see for example Acri, in the present volume).

An important tool for better understanding of the practical side of the religion, to which some contributors of our volume refer, are the epigraphical sources. Inscriptions, not only from India but also from South-East Asia, can provide us with the knowledge of actual ways of performing rites. ${ }^{5}$ Alexis Sanderson, writing about the limitations of the Śaiva literature as evidence of Śaiva reality, points out that one of these limitations is the prescriptive character of the sources which " $(. .$.$) means that they tell Śaivas what to do and what to think$ (and why they should do so) but disclose very little about the prevalence of the practices and beliefs that they advocate, of where or when they originated, of where and when they spread, or of the institutional infrastructure and patronage that enabled and sustained these developments". 6 Therefore epigraphical sources coming from the places and objects of worship, temples, pilgrimage centers, inscriptions on stone and copper plates, even if, as Sanderson notices ${ }^{7}$, incomplete and uneven, can overcome at least some of these limitations. ${ }^{8}$

5 See for example Colas 2005, Sanderson 2003-2004, 2013.

6 Sanderson 2013: 215.

7 Sanderson 2013: 218.

8 Sanderson (Sanderson 2013: 218) says about inscriptions: "Supplemented by the evidence of the legends and depictions found on the seals and coin issues of certain kings they enable us to learn much more than the prescriptive texts reveal about the chronology, spread, and patronage of religious movements in India and beyond, to work towards a view of their relative 
The contributions to the volume inscribe in yet another very urgent mission of Indology connected with the preservation and research on original, unknown and unpublished sources. As G. Colas wrote: "A sense of historical urgency haunts any honest indologist who, in order to reach a more balanced picture of the history of Indian literature, cannot confine his research to well-known texts and Indian and Western views on them which took definite shape in the twentieth century. He has to save, edit and publish many manuscript works that are literally on the point of disintegrating."

These and many other subjects important for the recent Indological research have their exponents among the authors of the present volume.

In his article entitled "Vedic Predecessors of One Type of Tantric Ritual", Shingo Einoo demonstrates that the concept of various usages of the same ritual element in anticipation of different effects attested in Tantric texts might be traced back to the latest layer of the Vedic literature. His investigation starts with the passage from the Parātrimsikā (9-16), which reads that the mantra 'sauh' brings different results depending on the length of its mental recitation. Similarly, for example, the collection of rasstrabhrt mantras, intended to support the kingdom and applied originally at the specific moment of the Agnicayana, happened to be put into another ritual context and used independently for different purposes depending on one's wish. Moreover, in the Vedic context the same ritual element might be also interpreted variously depending on the level of the srauta ritual system. In the opinion of Einoo, this diversity of applications and interpretations of the same element might be connected to the Vedic belief in the extraordinary power of a śrauta sacrifice resulting in its various

strength in various regions and periods, and to see important elements of these traditions and their institutions that are not mentioned in the prescriptive literature or if mentioned are not emphasized."

9 Colas 2005. Here also we can find his very useful and interesting observations concerning the problems of researching Indian religious and ritualistic texts. 
efficacies. This leads the author to the conclusion: "We cannot assume direct relations between the Vedic and Tantric rituals but the ritual applications of one and the same mantra of a certain deity for a variety of effects may be understood as a remote survival of the firm belief of the Vedic Brahmins in their powerful ritual system."

The aim of Andrea Acri's paper entitled "The Śaiva Atimārga in the Light of Niśvāsaguhya 12.1-22ab" is to contribute to the understanding of the hardly documented stage of Śaivism. The text in question, namely the Niśvāsaguhya, belongs to the earliest known corpus of the Mantramārga that "was composed in a historical period in which the traditions of the Atimārga and Mantramārga shared several elements in common and were just beginning to differentiate themselves as distinct, and competing, systems of salvation within the Śaiva stream." The author concentrates on the verses of Niśvāsaguhya 12.1-22ab, which refer to the soteriological means and goals of the little known Atimārga groups of the Pāñcārthika Pāśupatas, the followers of Pramāṇaśāstras, the Kārukas and the Vaimalas. He attempts to show that some of these verses might be directly derived from the Pāśupata sources, whereas the others might be read as "revealing information on the self-perception of the Mantramārga in respect to Atimārga Śaivism."

The strategies of incorporation of the pre-existing practice of scrying (called prasenā, prasīnā, prasannā, pratisenā or senikā) into the Śaiva Mantramārga are discussed by Somadeva Vasudeva in the paper "Prasenā, Prasinā \& Prasannā: The Evidence of the Niśvāsaguhya and the Tantrasadbhāva". The reason behind appropriating them into the early Mantramārga must have been their significant popularity suggested by contemporaneous literary works. Still, as the author notices, in the case of the Saiva literary corpus, different attitudes towards the divination can be distinguished. Whereas the exegetical works almost neglect it (Abhinavagupta in his Tantrāloka does not mention it at all and his commentator Jayaratha refers to it in a simile), within the revealed scriptures, starting with the Niśvāsaguhya itself, it becomes a recurrent motif. Taking into account the extensive textual dependency between the Niśväsa corpus, the Svacchandatantra and 
the Trika's Tantrasadbhāvatantra demonstrated already by Sanderson, Vasudeva argues that despite sharing a supportive prognosticatory role in the ritual of initiation, we cannot "with the present evidence, establish a direct textual link between the prasena material found in the Nišvassaguhya and the Tantrasadbhāvatantra". In addition, since the Svacchandatantra does not mention the prasena, it cannot be considered as an intermediate source of reappropriation of this particular practice to the new theoretical frames of the Mantramārga.

Judith Törzsök's article entitled "Women in Early Śākta Tantras: Düıī, Yoginì and Säclhakì" attempts at exploring "the role of actual flesh-and-blood women rather than various (divine or less divine) manifestations of 'the female"'. The study is mainly based on the Brahmayāmala and the Siddhayogeśvarimata, both texts forming the earliest stratum of the Saiva literature dated between the $7^{\text {th }}$ and the $9^{\text {th }}$ centuries. Three categories of women involved in ritualistic matters are discussed: 1) a female ritual partner called dütī/śakti, who plays a rather instrumental role in the ritual performed by a male sädhaka, 2) human yoginis, namely women endowed with supernatural powers, who, if someone wants to acquire these powers, often become the object of ritual, 3) the least frequent female practitioner, called sādhakī/yoginī/bhaginī/strī, who is a female equivalent of a male sädhaka. Although, as the authoress remarks, the texts used by her cannot be treated as a serious source of historical and social data, they may suggest that, as far as śakta ritual is considered, the rights and roles of women were of some importance.

The paper entitled "On yantras in Early Śaiva Tantras" by Csaba Kiss is devoted to exploring the changing pattern of the usage of the term yantra in the historical context of Śaivism. Basing his observations on the Brahmayāmala and other early Saiva texts, Kiss notices that the association of a yantra with geometrical designes, so prevalent in the secondary literature on this subject, emerged gradually, most probably attested for the first time in the Netratantra. According to him, in the case of Saiva literature, the initial usage and meaning of the term yantra was much wider than in later works. With time 
passing, it started to connotate specific rituals aiming at acquisition of religious goals, and finally it was linked with rituals of black magic involving transgressive substances, figurines of targeted people and mantras inscribed on a birch-bark.

In his article entitled "Saiddhāntika paddhatis I. On Rāmanātha, the Earliest Southem Author of the Śaivasiddhānta of Whom Works Survive, and on Eleventh-century Revisions of the Somaśambhupaddhati", Dominic Goodall introduces the issue of the history of ritual manuals (paddhati). His main concem is the Natarajjapaddhati authored by Rāmanātha (second half of the $11^{\text {th }}$ century), the earliest dated South Indian theologian of the Śaivasiddhānta whose works are still extant. This particular work survived in a single manuscript kept in a Śaiva monastery at Tiruvāvatuturai near Kumbhakonam. The comparative study reveals that despite much less elegant and polished form, the Nataräjapaddhati might have been modeled on the Somaśambhupaddhati, an extremely important, often quoted and carefully written medieval Śaiva manual. Nevertheless, the close dates of the composition of both manuals and the stylistic "clumsiness" of the Natarājapaddhati provoke the discussion regarding the literary history of the South Indian Siddhānta. Goodall proposes the hypothesis that Rāmanātha might have had an access to the early, unimproved version of Somaśambhu's work, which would mean that its eleventh-century version circulated in several editions, different from the presently available one.

The regional context of the theory and practice of the ritual of a 'royal hunt' is the subject of S. A. S. Sarma's examination presented in the paper entitled "Pallivett!a, or the 'Royal Hunt', in Prescriptive Literature and in Present-day Practice in Kerala". The author studies several, usually religiously syncretic, Keralan manuals (paddhati) and compares their prescriptions with the actual present day practice of the 'royal hunt' (in Malayalam: pallivett!a) conducted in the Trivandrum Śñ Padmanābhasvāmī Temple and the Guruvāyūr Temple. As he notices, it seems that in the case of Kerala the description of this particular ritual was introduced by Nārāyaṇa in his Tantrasamuccaya, 
where it is shown as an integral part of the great annual festival (mahotsava). Taking into consideration such factors as the etymology of the term pa!llivettta (pa!lli in Malayalam language means 'anything related to royalty'), the performance of the 'royal hunt' just before the ceremonial bath, and considering hunting as a pleasurable activity of the king by Sanskrit authors, Sarma observes: "thus, even though, we do not find a clear relationship between the 'pallivettta' and royal consecration rituals, the hunt may be viewed as a pastime of the Lord, when He is compared to an emperor". Still, as Sarma concludes, although the paddhatis were composed for the purpose of guiding the temple priests, even in Kerala itself the practice of the royal hunt does not always follow their prescriptions in detail: certain ritual elements are adjusted to the local needs, others are omitted or, on the contrary, stressed.

The main issue of T. Ganesan's paper entitled "Lesser Known Śaiva Initiations: Critical Edition of Vijñānadīksāa Chapter of the Hitherto Unpublished Acintyaviśvasādākhyāgama, One of the Āgamas of the Śaivasiddhānta Tradition and Its Brief Presentation" is the text believed to be an upagama of the Cintyägama, which served as the source of authority for the authors of numerous ritual manuals and compilations. Besides supplying the critical edition of its Vijñānadīkșā chapter, Ganesan briefly presents the hardly ever discussed Śaiva initiations (diksāa) attested there. Having explained the general concept of initiatory system in the context of the Saivasiddhānta tradition, he focuses upon three less attested types of initiation, namely jñanna-, yoga- and vijñanadikșā, out of which the last two seem to be unique for the Acintyaviśvasādākhyägama.

The article authored by R. Sathyanarayanan, entitled "Five Great Sins (Mahāpātakas) with Special Reference to Śaiva Siddhānta", regards the methods of the expiatory procedures (prāyaścitta) as attested by the Smārta and Śaivasiddhānta sources. Having discussed the general features of the präyaścitta as well as different typologies of the deeds that are subjected to expiations, the author demonstrates that there are also significant differences in the treatment of reparatory rites 
as far as the smrti and Saiva literatures are considered. For example, whereas the former prescribes for this sake various methods of fasting and recitation of Vedic passages, the latter recommends the worship of mandalas, yantras, cakras etc. with the help of such seed-mantras as the five BRAHMA-mantras. Also the attitude towards the expiation for the five great sins (mahapātaka) is not the same: although in the context of Vedic sources they seem inexpiable, both Śaiva āgamas and the Prāyaścittasamuccaya allow a sinner to purify, provided he committed the sins unintentionally.

The main concern of Ewa Dębicka-Borek's paper entitled "How to Realize the Four Goals of Life by Means of mantra?" are the motives and strategies of the conceptualization of the four human goals, namely dharma, artha, kāma and mokșa, in the terms of the Vaiṣnava Pāñcarātra Tantric practice. For this sake the authoress examines the early layer of the Pãñcarātra literature, mainly the selected passages of the Sätvatasamhitā, which quite contrary to the later samhitās contains an extensive section dealing with magical rites. In its context, the consecutive purusārthas might be realized in a totally ritualistic way: they are achieved according to a wish with a help of supernatural powers (siddhi) acquired out of mastering the particular mantra, in this case the mantra of Narasimha. It seems, therefore, that from this point of view the purusarrtha-rites provide the people who were not able to realize the four goals in a traditional way, namely in the course of their life, with a quick method of their fulfillment.

In her paper entitled "When Gods Get Broken-the Theory and Practice of the jïrnoddhära and navikarana in the Pāñcarātrika Sources", Marzenna Czerniak-Drożdżowicz discusses the issue of renovation and replacement of images and temples. This problem, already treated in the vedāngas, silpa- and vāstusāstras as well as purānas, acquires a new dimension in the context of the Vaiṣnava Pāñcarātra. As the author points out, the Pāñcarātrika concept of the five modes of a god's existence, where one of them, i.e. arcāvatära, is regarded to be his real presence in the earthly representations, enables the intimate relation between the god and his devotees. Yet, the permanent 
presence of the god might be endangered by the imperfection of his image or the temple he resides in, caused usually either by damage or impurity, and therefore the techniques of dealing with such a spoilt structure have to be secured. Having discussed some terminological problems considering the term jirnoddhära (usually translated as 'reconstruction of the damaged') and navikarana (literally: 'making anew/ renovation'), Czerniak-Drożdżowicz quotes and analyses the relevant Pāñcarātrika sources presenting different aspects of broadly-understood renovation: the causes of damages, different treatment of various images and temples according to their origin and particular procedures regarding purifying, renovation or replacing of the damaged images.

The point of departure for the paper of Marion Rastelli, entitled "Sandhȳ Worship in the $14^{\text {th }}$ Century Pāñcarātra: Theory and Practice?", is a passage found in Venkațanātha's Pāñcarātrarakșā, which says that while performing the sandhyā, the Pāñcarātrin is not obliged to follow the samhitās of Pāñcarātra, but can follow the prescriptions of the Vedic Sūtras instead. Given that Veñkatanātha devoted the whole first chapter of his work to show that the samhitās of Pañcarātra do not contradict the Vedic texts, this particular statement seems ambiguous, even though the author himself gives three reasons for such a possibility: 1) most saṃhitās are lost, 2) no Pañcarātra tradition teaches or follows sandhyā prescriptions properly, 3) prescriptions of the Vedic Sūtras fulfil the requirements of the samhitās. Posing such questions as whether the Pāñcarātra Saṃhitās' prescriptions for the sandhya rites were pure theory at his time? and "what is actually the difference between the Pāñcarātric and the Vedic orthodox manner of sandhyā worship?", Rastelli compares and analyses the performance of sandhyā as presented by Venkkațanātha himself as well as prescriptions from Vedic Sūtras and from the samhitās of Pāñcarātra.

To conclude, the contributors to the present volume of Cracow Indological Studies address many crucial issues referring to the Śaiva and Vaișnava traditions. They present a manifold spectrum of topics, a fact that resulted in the collection of articles showing the unique 
expertise of their authors in many areas of the studies on Tantric traditions of South Asia.

We are very grateful to the contributors for enabling us to publish the results of their research in our journal and we would also like to thank all the reviewers for their invaluable comments.

\section{Marzenna Czerniak-Drożdżowicz \\ Ewa Dębicka-Borek}

\section{Sources:}

Colas, G. 2005. Rites Among Vaikhānasas and Related matters. In: J. Gengnagel, U. Hüsken and S. Raman (Eds). Words and Deeds. Hindu and Buddhist Rituals in South Asia. Wiesbaden: Harrasowitz Verlag.

Gengnagel, J., U. Hüsken and S. Raman. 2005. Editor's Preface. In: J. Gengnagel, U. Hüsken and S. Raman (Eds). Words and Deeds. Hindu and Buddhist Rituals in South Asia. Wiesbaden: Harrasowitz Verlag.

Humphrey, C. and J. Laidlaw. 1994. The Archetypal Actions of Ritual. A Theory of Ritual Illustrated by the Jain Rite of Worship. Oxford: Clarendon Press.

Michaels, A. 2005. General Preface to the "Heidelberg Studies in South Asian Rituals". In: J. Gengnagel, U. Hüsken and S. Raman (Eds). Words and Deeds. Hindu and Buddhist Rituals in South Asia. Wiesbaden: Harrasowitz Verlag.

Sanderson, A. 2003-2004. The Śaiva Religion Among the Khmers, Part I. Bulletin de l'Ecole française d'Extrême-Orient, 90-91 (2003-2004): 349-463.

Sanderson, A. 2013. The Impact of Inscriptions on the Interpretation of Early Śaiva Literature. Indo-Iranian Journal 56 (2013): 211-244.

Timm, J. R. (ed.). 1992. Texts in Context. Traditional Hermeneutics in South Asia. Albany: SUNY Press.

White, D. G. 2001. Introduction. In: D. G. White (ed.). Tantra in Practice. Delhi: Motilal Banarsidass. 